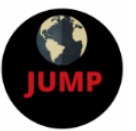

ISSN: 2574-3465 Print/ ISSN: 2574-3481 Online

Volume 1, Issue 1 (2017), pp. 66-79

(C) Journal of Underrepresented and Minority Progress

http://minorityprogress.org/

doi: 10.5281/zenodo.1165456

\title{
African American Students in the Community College Classroom with White Teachers
}

\author{
Denise Erskine-Meusa \\ Morgan State University, United States
}

\begin{abstract}
The purpose of this qualitative study was to examine African American student pedagogical experiences in classrooms with White teachers at a community college in the Mid-Atlantic region of the United States. The intent of the study was two-fold: (a) to search for evidence of how culture shapes African American students'view of themselves, and (b) to explore how African American student pedagogical experiences with White teachers shape their attitude about school. The results of this study revealed that many of the White teachers experienced by the research participants demonstrated some aspect of colorblindness in their pedagogical practices. The results also found that the African American community college students in this study valued the use of culturally responsive pedagogy in the classroom.
\end{abstract}

Keywords: Africa American students, qualitative study, colorblind, students, higher education

Having an understanding and sensitivity to how African American students learn, through culture (Ladson-Billings, 1994), can improve graduation rates. The way all students learn is linked to their culture, social setting, and learning style (Vygotsky, 1978). Vygotsky was a psychology scholar who was not satisfied with mainstream psychology. He called for a sociocultural psychological method for recognizing that human beings learn by using language and other tools that are available to them within a social context. My research (Erskine-Meusa, 2016) suggests that being sensitive to culture when teaching diverse students, particularly African American students, is a prerequisite for facilitating positive learning experiences that are engaging and relevant.

Major proponents of the need for teachers to connect culture with cognition contend that teaching strategies must match the culture of certain ethnic groups, or the students will experience higher levels of academic failure (Delpit, 1995; Gay, 2010; Ladson-Billings, 1994; McPhail \& McPhail, 1999; Vygotsky, 1978). Before I provide the background of my study and its outcome, it is important to define and understand the meaning of "race" and culture and how culture is connected to learning.

An individual's culture is often mistakenly identified as "race." However, race is an artificial social construct that has no scientific basis because there are no biological or genetic markers that define race (Cox, 1979; Diop, 1974; Fields, 1982; Helms, 1990). Race is a psychological phenomenon that has nothing to do with skin color or other physical attributes. 
However, the visual or physical differences of eye color, eye shape, skin color, body shape, and hair form has been used to classify individuals into biological or genetic and distinct arbitrary categories of people (Cox, 1979; Herbes-Sommers, C., Strain, T., Smith, L., 2003). Though most biologists and anthropologists do not support the concept of race, these external differences are commonly accepted by society as a method for explaining internal human differences, such as athletic ability, musical aptitude, and intelligence (Herbes-Sommers, C., Strain, T., Smith, L., 2003). The concept of race is an illusion, but culture is not.

Human beings need culture to think, intellectualize, create meaning making, reflect, and understand the world they live in. Unlike the term "race" that is inaccurately and often used to describe racial phenotypes, culture has much to do with how humans function. Culture is allencompassing and what makes us human-it is what makes us tick. In other words, "we do not really see through our eyes or hear through our ears, but through our beliefs" (Delpit, 1995, p. 46). Culture is a learned system of shared beliefs, knowledge, customs, memories, common values, language, traits, behaviors, artifacts, and attitudes that belong to a specific group or society that are transferred from generation to generation (Berko, Wolvin, Wolvin \& Aitken, 2014; Tylor, 1871).

Culture is equivalent to living. Diop (1974) argued "people live their culture - the roots of their culture are inseparable from their linguistic structure and historical past" (p. 122). The function of the human brain is influenced by culture (Triandis, 1994). Thus, it is through our cultural lenses that we understand our lived human experiences and make sense of the world. Essentially, culture helps to shape judgement, perception, how we see others and ourselves, and aids in our cognitive development and the learning process (Vygotsky, 1962). According to Palmer (2007), the "human brain works best with information presented, not in the form of isolated data bits, but in patterns of meaningful connection" (p. 130). The concept of culture is essential for understanding how African American students learn.

\section{Background of the Study and Conceptual Framework}

Even though more than half of African American students are enrolled in community colleges (American Association of Community Colleges [AACC], 2014; Smith \& Vellani, 1999), only $31 \%$ of public community college students go on to graduate with an associate degree in six years (Roach, 2009). In 2009-2010, African American students earned $13.7 \%$ of all associate degrees issued by community colleges, followed by Hispanics, who earned $13 \%$ (National Center for Education Statistics (NCES), 2014). In that same academic year, Whites earned $66.3 \%$ of all associate degrees (NCES, 2014).

African American students are not graduating from the community college at the rate of their White counterparts. Complete College America (2011) reported that only $7.5 \%$ of these students who attended school full-time graduated. In fact, most African American students are not full-time students. And among those who attend community college part-time, only $2.1 \%$ of these students graduate in three years (Complete College America, 2011).

I created the CPE to organize and categorize the perceived pedagogical experiences African American students had with White teachers. The CPE uses Bennett's (1986, 1993) Development Model of Intercultural Sensitivity (DMIS) as its framework. The original purpose of the DMIS was to explain how people experience and react to cultural differences (Bennett, 1986). The DMIS outlined "statements about behavior and attitudes at each stage that are indicative of a particular condition of the underlying worldview" (Hammer \& Bennett, 2001, p. 12). 
DMIS provided the framework for the CPE in creating the cognitive lenses through which to interpret White teachers' perceived pedagogical practices, actions, and outlook towards cultural difference, as experienced by the African American students in this study. CPE provided an explanation for classroom practices that resembled Eurocentric or culturally responsive stages of growth, or the extent to which cultural differences were recognized and accepted. According to Bennett, "each stage is meant to characterize a treatment of cultural difference that is fairly consistent for a particular individual at a particular point of development" (1993, p. 27). At the broadest level, the DMIS continuum is essentially a binary with ethnocentrism on one end and ethnorelativism on the other. Beneath both of the two major divisions are three smaller ones, forming a total of six stages of denial to integration. All six stages of growth, arranged from the most ethnocentric to the most ethnorelative, are as follows: "1. Denial, 2. Defense, 3. Minimization, 4. Acceptance, 5. Adaptation, and 6. Integration” (Bennett, 1993, p. 62).

The first category within ethnocentrism is Denial. For this dissertation, an example of an experience with a White teacher that can be categorized as being at the 'Denial' stage is reflective of individuals who come from areas where they intentionally isolated and separated themselves within homogenous groups (Kelso, 2006). They tend to be an individual who sees others as inhuman, less intelligent, or culturally deviant. These individuals also consciously seek out environments that supported and protected their worldview (Kelso, 2006).

The concept of School Wounds (Olson, 2009) is situated within the 'Denial' stage of the CPE. 'School wounds' is a term that describes treatment of students that makes them feel inferior, ashamed, and marginalized. Therefore, they are often "reluctant or anxious" when learning (p. 29). Olson contended that school wounds can be described as not having a sense of pleasure in learning and "if pleasure is disconnected from cognitive tasks, we are wounded" (p. 34). School wounds are often produced in educational environments where students feel a heightened sense of shame because they are different (Olson, 2009).

School wounds contain seven categories that describe how students might be feeling if they are wounded. The concept of 'school wounds' helped me to analyze and provide an assessment and understanding of whether or not students have experienced or been impacted by school wounds at the 'Denial' stage of CPE, and, if so, how.

The 'Defense' stage is the second category of the DMIS. In the 'Defense' stage, one's culture is considered the only way to live, and as a result, the person exudes great hostility toward cultures that are different. These individuals also tended to feel their culture is threatened by difference (Kelso, 2006). An example of a White teacher at the 'Defense' stage would be an individual who negatively evaluates other cultures that are different. At this stage, the White teacher also demonstrates cultural superiority by only discussing positive aspects of White culture. For example, the White teacher may say things like "Why don't these people speak my language?" or 'My culture should be the model for the rest of the world.'

Midway through the continuum is 'Minimization,' in which elements of an individual's own cultural worldview are the standard for all human existence. According to Bennett, M. (1993, p. 46), minimization is characterized as "burying differences under the weight of cultural similarities" or when differences are minimized. For this conceptual framework, "Minimization" is as follows: Minimization can also be described as colorblindness because it correlates with White teachers, for example, who do not have substantive experiences, direct knowledge about, or minimal shared interactions with the diverse students they teach (Hodge, 2003). During these instances, it is possible that these individuals may be unaware of holding stereotypical or prejudicial outlooks and biases toward the diverse students they teach, which is a form of 
colorblindness (Hodge, 2003; McIntyre, 1997; Valli, 1995). According to Sullivan (2006), colorblindness is employed by people who wish to minimize race, see themselves as not recognizing race or racism or being "racially neutral" (p. 61).

The second category within DMIS that contains the final three stages is called ethnorelativism, which was used to explain classroom practices that resonated with culturally responsive teaching. Ethnorelativism believes that no one culture is superior to another (Bennett, 1995). Individuals at the ethnorelativism stage search for substantive ways to adapt to difference (Bennett, 1995). These individuals value the different cultural contexts in which distinctive cultural groups live and function.

These stages are called Acceptance, Adaptation, and Integration. 'Acceptance' establishes the fourth stage within the second category of the intercultural continuum. This stage portrays some level of respect for differences and a tolerance for behaviors, values, attitudes, and beliefs different from one's own. At this stage, the White teacher, for example, may see "culture as offering alternative viable solutions to the organization of human existence" (Bennett, 1995, p. 6). They may also understand the differences in language, mannerism, communication styles and social behavior such as values, beliefs, and attitudes (Kelso, 2006). At the 'Acceptance' stage, "it does not mean agreement or preference for alternative values but rather acceptance of the distinctive reality of each culture's worldview

The fifth stage in the continuum is 'Adaptation,' in which individuals show respect and empathy toward others and adapt personal behaviors according to the cultural context of a given situation. This is the point in the skill stage where the individual is in the "process of developing intercultural sensitivity" (Kelso, 2006, p. 69). The 'Adaption' stage is the point at which the individual experiences cultural competence and sensitivity. These individuals also demonstrate an ability to adapt to situations where they can effectively engage in interpersonal communication with individuals from different cultures.

Finally, within the 'Integration' phase of the continuum, one maintains one's own culture while adapting to certain aspects of other cultures. This is the most fluid stage of the continuum. 'Integration' of cultural difference is the state in which one's experience of self is expanded to include the movement in and out of different cultural worldviews. People at the 'Integration' stage "often are dealing with issues related to their own cultural marginality" (Bennett, J., 1993, p. 112). An example of a White teacher at the 'Integration' stage would be an individual who embraces their culture and the culture of others. Accepting the culture of others and with no biases, suggests that an individual respects the uniqueness of any distinctive cultural group that is different from their own.

The ethnocentric stages within the CPE scale were used to interpret African American student experiences with White teacher classroom practices that may be categorized as expressing traditional teaching practices, or the "banking system." Conversely, the continuum's ethnorelativistic stages were used to adequately interpret and categorize students' pedagogical experiences as reflecting culturally responsive classroom practices. Culturally responsive classrooms reflect student-centered instruction that advocates for cultural competence, sociopolitical consciousness, and academic excellence (Ladson-Billings, 1995). These classrooms use the culture of the student as a vehicle in which to effectively teach them.

The CPE scale seems appropriate for interpreting, categorizing, describing, and understanding African American community college students' perceived experiences with White teachers for this study. Bennett's DMIS and Olson's school wounds concept served as the framework for the CPE. It helped me to understand and interpret African American students' perceived experiences with White teachers' classroom teaching practices and attach meaning to 
them. Because the CPE scale helped categorize and interpret African American students' perceived experiences with White teachers' classroom practices for this study, it was the most appropriate method by which to try to understand African American participant pedagogical experiences in White classrooms.

\section{The Study Site}

To address the research problem, the main research question was, what are the classroom experiences of African American community college students taught by White teachers? This study was conducted at a specific research site-a Mid-Atlantic two-year institution. It is located in a large metropolitan city in the Mid-Atlantic region of the United States. Although the student population at the project site's main campus consists of 16,286 individuals, data from in-person, in-depth, semi-structured interviews are limited to referrals from African American study site administrators and faculty, as well as from a group of six African American students selected for individualized in-person interviews. This study may not represent all classroom experiences of African American community college students pursuing an associate degree at this two-year institution or any other community college. Essentially, the varied experiences, beliefs, attitudes, values, experiences, and opinions of the research participants may not lead to findings that are generalizable.

\section{Student Stories}

To reflect the study's conceptual framework, which is based on the CPE (Erskine-Meusa, 2016) and the CNIM (Cross, 1991), the following stories reflect student perspectives, values, and experiences, how they see themselves as Black people, and concepts of learning. The stories are also categorized as positive and negative experiences the research participants had with White teacher classroom practices at DCC. The purpose of these stories was to seek multiple narratives to understand how these participants construct meaning of their experiences with White teachers. The following stories reflect their structures of consciousness, as experienced from their point of view and how they interpreted those experiences.

\section{Positive Experiences in White Classrooms}

Positive experiences in White classrooms correlated with classrooms that reflected culturally responsive teaching. In this section, I use the ethnorelativistic stages of CPE to describe culturally responsive teaching. Nadra discussed how she enjoyed being part of a classroom discussion regarding the Trayvon Martin and Michael Brown cases, human rights issues she felt were relatable and meaningful. Nadra explained:

I had a White teacher that was amazing. She took the time to engage us in conversation. She adds PowerPoints as well, and she adds pictures to the PowerPoints, which adds a little humor to it so that it is more relatable to us. We were able to talk freely, ask questions, engage in a conversation, and interact with her as the professor. 
Clearly, being able to ask questions of the instructor and engaging in class discussions were very important to Nadra. Remington shared the same sentiment about the importance of discussions in the classroom:

The best learning experience was my art appreciation class. The entire class time dealt with understanding and discussing what we were looking at and sharing ideas and hearing what the teacher had to say and what other students had to say. That was my best learning experience because we got to see other points of view, and we got to understand the material better. I felt like I learned something and I understood. I liked that class a lot because it focused on discussion and communication between the teacher and students.

Remington believed it was important for teachers to forge connections with students, so they understand what is expected of them. Remington specifically discussed one White teacher who did express a sense of caring about his ability to learn and pass the class. Remington stated:

I had about six weeks left in the semester. I hurt my hip, and I
was on crutches. I had to stay home for some time. I didn't want
to drop my classes because I had good grades. So, I went to my
teacher, and she was White. She worked with me, and she really
understood. Sometimes she worked with me over email, and I
managed to get an "A" in the class even though I couldn't show
up for that last half because she made sure I got everything. She
made sure I had a friend in the class that could give me the stuff.
She actually made sure I passed, and that was an English 101
class that I really needed to pass. If I had dropped the class, it
would have set me back a lot. She really helped me out.

Because this White teacher was willing to help Remington succeed, he did. His injury was an uncontrollable event. Fortunately, for Remington, he had a teacher who was caring enough to work with him, meet his needs, and ensure academic success. Because of this experience with a caring teacher, which is located within the 'Acceptance' stage of the CPE scale, Remington was able to take all his classes in proper sequence, without any gaps in between, and will graduate on time.

Like Remington, Shaquille enjoyed classes that were engaging and interactive. Shaquille's narrative expressed experiences with a White teacher that can be classified as being within the 'Integration' stage of the CPE scale. He admitted he had a very short attention span and that he really enjoyed class exercises that involved anything from lying on the floor with his eyes closed looking at the ceiling, to group work. He's done monologue work, group projects, and reports. He's taken creative writing courses and engaged in think tanks and class workshops to share student writing projects and have classmates comment on it. For Shaquille, the best way to be taught is through metaphors and references that are relatable to him, such as when he listens to music. In fact, the best learning experience he had at the college was in a directing class that was taught by a White teacher. Shaquille stated:

It was the best acting class I've taken because it allowed me to sit outside what the actor normally does and get an idea of what 
the director does, and it gave me that hands-on feel. Her teaching style is so good. It's just clean and crisp. It's something that I enjoyed, which is why I took so much away from it. We did have a book, and we did have to read from the book, even though we had homework assignments. Instead of doing a written assignment and submitting it for a grade, we would all do blocking exercises to balance the stage. So, even if you get a bad grade on what the assignment actually was, you don't forget what you actually learned, and you actually take away from the experience, as opposed to a lot of teachers wanting to give you homework and then grade it. They may mark what is wrong on it, but that doesn't necessarily mean you know why it's wrong. I really like when any teacher puts me right in the thick of it so I can find out whether or not I'm right or wrong so I can find out what I need to do to correct myself.

Clearly, acting is Shaquille's passion. The following narrative demonstrates that the White teacher is at the 'Integration' stage of the CPE scale. He explained that he learns best when culture is part of the classroom lesson:

I was taking a voice class, and my professor was like, "You got to rub flavor on it. You're Black; it's OK to embrace your Blackness. It's OK to let your body tell you what to do." She was really saying, "Let your African American roots influence what you're doing." In theater, a lot of what we do teaches us to eliminate our habits. Those habits are what we do to hinder us from making other characters that are believable. So with this teacher, it was nice to know that.

Discussion time is an essential part of learning for study participants. Shaquille's narrative demonstrated that students must be able to express their culture in the classroom. Discussion supports the learning process and helps students to learn material when teachers take the time to explain what students need to know. Clearly, having teachers who try to explain material and provide students with extra time to complete work is important. Teachers who encourage students to succeed help students to experience positive academic outcomes. When students have positive experiences, such as Shaquille's, it allows students to feel respected and cared for. This in turn, produces feelings of positive self-worth and positive student self-efficacy. Shaquille's experiences support the idea that positive classroom experiences enhance students' perceptions of their academic skills (Pascarella \& Terenzini, 2005).

\section{Negative Experiences in White Classrooms}

Negative experiences in White classrooms correlated with classrooms that reflected traditional classroom practices. In this section, I use the ethnocentric stages of CPE to describe these pedagogical practices. Nadra wishes to have teachers who are receptive and open to questions. She expressed that having teachers who are approachable help her to learn. For example, she said: 
If you don't have office hours or ever check your emails, it makes it kind of hard to ask questions if I don't really understand something. Or if a professor tends to rush through the lectures, it makes it pretty difficult to understand and comprehend everything they are talking about. Especially if they are shooting through five or six topics at one time or glaze [sic] through everything as if we all have the same understanding as they do.

Nadra mentioned she had difficulties approaching a White professor whose teaching practices she perceived to fit within the 'Denial' stage of the CPE scale. Nadra thought he was biased against non-White students: Nadra said, "I had a racist professor. That was hard because he didn't particularly care for the students of color that were in the classroom." When I asked her how she knew he was racist, she countered:

Because you could tell that we couldn't get anything higher than a B. And then for some students, you could tell that their work was lackluster, and I pride myself on having great work, and he would find the smallest things to critique. So he would say that if your grammar was bad here, then "points off," but for other people who were White, who did similar things, points were not taken off for that. We students had a chance to compare notes and discuss it outside of the classroom.

Nadra became visibly upset when talking about the teacher she called racist. She said:

This teacher taught philosophy. It was widely understood that he was a racist. We were all aware of it. No one really talked about it because we knew that that was the case. We knew we just had to work extra hard to make it out of the class. I ended up with a C. I still, to this day, believe I could have left that class with a B, but there was nothing much that we could do. I don't think he works here anymore because I have not seen him since.

I probed further by asking if the experience was something she felt was culturally relevant. I wanted to know whether the teacher referenced her culture in the classroom. She replied:

\section{Absolutely, it was relevant for him! He said he was German and that it was part of his culture to not particularly care for other people from other races. He made it perfectly clear to us that that was who he was.}

Nadra has had her share of difficult teachers; and with her frank storytelling, I was able to discern that she has developed a tough exterior as a result. Her obstacles with difficult teachers did not deter her from pursuing her educational goals. In fact, she asserted that difficult White teachers were something to which she had grown accustomed. She explained that although the experience with the White German teacher affected her transcript negatively, it did not affect her feelings about her ability to succeed: 
Did it affect me personally in terms of whether I thought I was a bad student? Absolutely not! I was not hurt receiving a " $C$ ", because it was not my first time experiencing a racist White teacher. In high school, I had to deal with the same thing, so I wasn't hurt. I'm used to it, and I adjust because I'm used to it. I realized it was not personal. I recognized it wasn't me that he doesn't like, that it is his problem. It wasn't about me; it was about him.

Despite Nadra's experience with this White teacher, she was not wounded by it. It did not negatively affect her student self-efficacy. She was able to learn from that experience and not let it impact her feelings of self-worth and her ability to succeed.

Remington shared an experience he had with a teacher who seemed uncaring. His narrative placed his perceived negative experiences with White teachers within the 'Denial' stage of the CPE scale. He discussed how he felt that some White teachers were not caring enough and not willing to make exceptions. For example, he once had to be rushed to the emergency room to receive stitches on his hand and was unable to attend class the following day. He was unable to provide a note to explain his absence to the teacher because he had forgotten to ask for one. He explained:

There's no room for error. For instance, for my gym class, I missed class because I received stitches. I did not go to gym because I could not participate. I was literally in the hospital a few hours before classes were supposed to start. I also wanted to sleep after being in the hospital all night. And she still gave me an unexcused absence because I wasn't there. I felt like I was being punished for something that was completely out of my control. This class was the most stressful because I ended up losing points for nothing, and it really didn't make any sense. She would not excuse me because I did not bring a note, and it was too late. I feel that every time I mess up, White teachers act like it's not their problem, and that it is my fault, and that it is too bad for me. Ifeel like there is no leniency. I felt hurt. It felt personal. I felt like, "Wow, do you know me? Do you know exactly what happened, and you cannot make an exception? It's not like you're going to be fired because you're not taking points away from me. I just didn't understand that. I didn't understand that at all.

This experience and the one that follows demonstrated that Remington was wounded by the experience. This specific experience can be best described as falling within the 'Wounds of Average' category of the CPE because he felt the teacher did not care whether or not he performed well in the class. Remington discussed an experience he had with a White teacher he had when he had broken his hip:

I had some teachers who took the grading rubric way too serious even though I knew they could bend a little bit because they were the teacher, and they didn't seem to give me any 
leniency when I had something going on at home. I'm not even given an opportunity to explain why I missed an assignment or something. This hurt my grade because most classes you get grades for showing up to class and participating in class, and I had a legitimate reason for not coming to class. I understand that I can't get points because I wasn't there. But because I had a legitimate reason for not being there, I feel I should have been excused. It just didn't seem right to me. It did hurt my grade, and I lost points in a class which I should have easily received an A for, a gym class. Now, I have to learn to fight back and get extra points for work on an absence that wasn't my fault. It ended up hurting my grade, and all I'm here for is to get a good grade.

Remington felt his illness was out of his hands and that the teacher could have been more caring. Clearly the experience was frustrating for him, and he demonstrated 'Wounds of the Average,' when he took it very personally.

Shaquille has had experiences with White teachers who he felt did not care that he learned the material and suffered from 'Wounds of the Average.' He said:

I wasn't able to connect to a teacher's teaching style. I took a math class, and I'm very bad in math. I'm a right-brained individual. I took a math class, and I couldn't understand what the teacher was saying. So that made it hard for me to learn.

Unfortunately for Shaquille, he had a teacher who did not ensure students understood his explanations. Because of this experience, Shaquille was unable to learn the material as well as he could have.

Most of the data collected in this study occupied the two extremes of the continuum. Many of the students in this study claimed their teachers were very nice, treated everyone fairly, and did not "play favorites." Some participants explained their teachers were very effective with recognizing students' unique experiences in the classroom by allowing them to express themselves and engage in conversations or by including topics related to racial oppression, current events, or other social issues students could relate to during class discussions.

The positive student experiences with White teachers fell mostly within the sixth stage of the CPE. In the final stage, called the 'Integration' phase, White teachers maintained their own culture while adapting to certain aspects of student cultures. Essentially, at the "Integration" stage, all student participants, at some point, were treated with respect, enthusiasm, empathy, compassion, and great care by their teachers.

Conversely, negative experiences with White teachers who seemed inflexible in their classroom practices fell within the first or third ethnocentric stages, 'Denial' and 'Minimization.' Remington, Awa, Shaquille, and Nadra, who were at the 'Internalization' stage of the CNIM, experienced some White teachers at the 'Denial' stage. This 'Denial' stage reflects a teacher that is in complete denial that there are different ways of seeing the world, or there is denial of cultural differences. 


\section{DISCUSSION}

I attempted to describe positive and negative classroom experiences and to paint a picture of what it is like for African American students in White classrooms in the community college. CNIM highlighted the student's overall demeanor, perspective of themselves, and their concept of learning. CPE provided the lens with which to understand student descriptions and student stories of what classrooms are like for a particular group of African American students at DCC. CPE helped to facilitate an understanding of how the student participants felt when they did not believe they were supported and nurtured by White teachers.

As a researcher, I sought to interpret African American student narratives of classroom experiences with White teachers at Diop Community College, located in the Mid-Atlantic portion of the U.S. to develop a better understanding of their educational needs. As African American students are graduating at significantly lower rates than their White and Asian counterparts and are widely taught by White teachers (Cohen \& Brawer, 2010), it was hoped that a better understanding of how African American students experience White teachers would shed some light on how to mitigate their dismal graduation rates and, subsequently, address their educational needs.

The findings of this study produced five salient themes: a) culturally congruent teaching practices, b) caring teachers, c) cultural influences; d) colorblindness; and e) school wounds. These themes emphasized the need for the community college to continue its role in providing equal educational opportunities for all who seek it. Unfortunately, there are many classroom pedagogical inequities that negatively impact the community college mission, particularly for African American students. Regarding negative student experiences, these students, primarily, refer to a White teacher, for example, who recognizes the humanity of all people regardless of culture, but sees all cultural groups as the same. When this happens, an African American students' culture is devalued because their values and unique differences from White culture are not respected. The assumption of similarity predisposes the White teacher to avoid recognizing "one's own cultural patterns, understanding others, and eventually making necessary adaptations" (Bennett, 2011, p. 5).

Rooted in the holistic and storied classroom experiences of African American community college students with White teachers, the findings provided a glimpse into the souls of a group of African American students. My positionality as a Guyanese immigrant, community college teacher, community college graduate, and researcher gave me an opportunity to delve into the cultural reflections of study participants to understand and describe how they experienced culture in the classroom and its impact on their educational outcomes. Like Du Bois' (1903) "The Souls of Black Folk," which promulgated the importance of people of African descent to have the right to a good education, the outcome of this study does the same.

Since the early thirties, both Dr. Carter G. Woodson (1933) and Dr. W.E.B. DuBois proclaimed (1935) the need to discuss the underachievement of African American students. They posited that the educational system demonstrates poor-quality, rendering it ineffective. It is now 2016 and the landscape of education for African Americans has not changed. It is not adequately preparing these students for the future. To a large extent, the current educational system kills creativity, and individuality, and has been intellectually abusive. It must teach students to be collaborative rather than competitive. Teachers must teach students how to think instead of what 
to think. Education needs to be about more than receiving and acquiring information but also about processing information in a way that builds intelligence.

African American students continue to lag behind their White and Asian counterparts. As it stands, the American community college should be held accountable for engaging in educational malpractice and should not be acquitted. This qualitative study serves as a call to action to college administrators and faculty to facilitate a seismic shift in the way African American students are taught. The student voices provided additional valid evidence of the pressing need for using culture as a resource for improving classroom teaching and learning.

The evidence in this study indicates that students need teachers who care about the method of their instruction. They need teachers who care about them. The classroom is the cultural incubator for producing creative and intellectually stimulated students who are passionate about learning. I believe that by using culturally responsive pedagogical practices in the classroom there can be a substantive rise in African American community college graduation rates. As it stands, the community college's "Open Door" looks more like a pinhole because African American students' rate of completion is dangerously low because they are barely graduating. It is with a strong sense of urgency that the community college must widen those doors and mandate a change in instruction. It is my hope that this study will serve as an educational manifesto for community college classrooms to demonstrate teaching practices that help students develop into intellectually stimulated individuals that are culturally competent.

This study's narrative evidence dictates that a change in teaching practices among faculty can make a difference in educational outcomes for African American students. Higher education is a democratic ideal that cannot be compromised, and when done correctly, it can destroy many of the barriers to retention and degree completion for these students. With the institutionalization of cultural pedagogical frameworks that adequately meet the cultural needs of diverse student populations in classrooms, the "open doors" of the community college will truly be open.

\section{REFERENCES}

American Association of Community Colleges (2014). Community college enrollment. Retrieved from http://www.aacc.nche.edu/AboutCC/Trends/Pages/enrollment.aspx

Bennett, M.J. (1986). Towards ethnorelativism: A development model of intercultural sensitivity. In R.M. Paige (Ed.), Cross-cultural orientation: New conceptualizations and applications ( $p p .27-70$ ). Lanham, MD: University Press.

Bennett, J. M. (1993). Cultural marginality: Identity issues in intercultural training. In R. M. Paige (Ed.), Education for the intercultural experience (2nd ed., pp. 109-135). Yarmouth, ME: Intercultural Press.

Bennett, M. (2011). A Developmental Model of Intercultural Sensitivity. Retrieved from http://www.idrinstitute.org/allegati/IDRI_t_Pubblicazioni/47/FILE_Documento_Bennett_DMIS _12pp_quotes_rev_2011.pdf

Berko, R., Wolvin, A., Wolvin, D., Aitkin, J. (2014). Communicating: A social, career and cultural focus. New Jersey: Pearson.

Cohen, A., \& Brawer, F. (2010). The American community college. San Francisco: Jossey-Bass.

Complete College America. (September, 2011). Time is the enemy: The surprise truth about why today's college students aren't graduating....and what needs to change. Retrieved January 8, 2015 from http://www.completecollege.org/docs/Time_Is_the_Enemy_Summary.pdf

Costner, K. L. (2003). The struggle still continues: Faculty willingness to teach African American learners (Unpublished doctoral dissertation). Morgan State University, Baltimore, MD.

Cross, W. E. (1991). The Cross and Thomas models of psychological Nigrescence.Journal of Black Psychology 5, 13-19. 
Cox, O. (1979). Caste, Class, and Race: A study in social dynamics. New York: Monthly Review Press.

Delpit, L. (1995). Other people's children: cultural conflict in the classroom. New York: The New Press.

Diop, C. (1974). The African origin of civilization; Myth or reality. New Jersey: Lawrence Hill Books.

Du Bois, W. E. B. (1903). Souls of black folk. Chicago: A.C. McClurg and Company.

Durant, T. L. (2005). Culturally mediated instruction: Awareness, relevance and implementation in community colleges (Doctoral dissertation). Morgan State University, Baltimore, MD.

Erskine-Meusa, D. (2016). Culture Matters! African American Students. White Community College Teachers: A Case Study of Cultural Differences and Their Consequences.

Fields, B. (1982). "Ideology and Race in American History." Pp. 143 - 177 in Region, Race, and Reconstruction: Essays in Honor of C. Vann Woodward, edited by J.M. Kousser and J. M. Mcpherson. New York: Oxford University Press.

Gay, G. (2010). Culturally responsive teaching: Theory, research, and practice. New York: Teachers College Press.

Hammer, M. R., Bennett, M. J. (2001). The intercultural development inventory (IDI) manual. Portland, OR: Intercultural Communication Institute.

Herbes-Sommers, C., Strain, T., Smith, L., (2003, April 24). Race: The power of an illusion. [Video file]. Retrieved from https://www.youtube.com/watch?v=Y8MS6zubIaQ

Helms, J. (1990). Toward a model of White racial identity development. New York, NY: Greenwood Press.

Hodge, S.R. (2003). From ethnocentrism to ethnorelativism: Advocacy for implementing diversity training and multiculturalism in PETE programs. Chronical of Physical Education, 14(3), 15-16.

Howard, G. (2006). We can't teach what we don't know: White teachers, multiracial schools. New York: Teachers College Press.

Irvine, J., Armento, B. J. (2001). Culturally responsive teaching: Lesson planning for elementary and middle grades. New York: McGraw-Hill.

Kelso, D. (2006). An empirical investigation of the intercultural sensitivity of student affairs practitioners at a Midwest metropolitan university (Doctoral dissertation). Indiana State University, Indiana.

Ladson-Billings, G. (1994). The dream keepers: Successful teachers of African- American children. San Francisco: Jossey-Bass.

McIntyre, A. (1997). Making meaning of Whiteness. Albany: State University of New York Press.

McPhail, C., \& Costner, K. L. (2005). Eight principles for training a culturally responsive faculty. The Department Chair, 16(2), Issue 1.

McPhail, I., \& McPhail, C. J. (1999). Transforming classroom practice for African American learners: Implications for the learning paradigm. Removing Vestiges: Research Based Strategies to Promote Inclusion, (2), 25-35.

National Center for Education Statistics. (2014). Fast Facts. Retrieved from http://nces.ed.gov/fastfacts/display .asp?id=72

Olson, K. (2009). Wounded by school: Recapturing the joy in learning and standing up to old school culture. New York: Teachers College Press.

Palmer, P. (2007). The courage to teach: Exploring the inner landscape of a teacher's life. San Francisco, CA: Jossey Bass

Pascarella, E. T., \& Terenzini, P. T. (2005). How college affects students: Findings and insights from twenty years of research. San Francisco: Jossey-Bass.

Roach, R. (2009, May 14). The community college transfer challenge. Retrieved January 16, 2015 from http://diverseeducation.com/article/12559/

Sleeter, C. (2011). An agenda to strengthen culturally responsive pedagogy. English Teaching: Practice and Critique, 10(2) 7-23.

Smilkstein, R. (2003). We're born to learn: Using the brain's natural learning process to create today's curriculum. Thousand Oaks, CA: Sage Publishing.

Smith, J., \& Vellani, F. (1999, Fall). Urban America and the community college imperative: The importance of open access and opportunity. In R. C. Bowen \& G. H. Muller (Eds.), Gateways to democracy: Six urban community college systems (pp. 30-50). San Francisco: Jossey-Bass. 
Sullivan, S. (2006). Revealing Whiteness: The unconscious habits of racial privilege. Indianapolis: Indiana University Press.

Tylor, E. (1871). Primitive cultures: Researches into the development of mythology, philosophy, religion language, art, and custom. London: John Murray.

Triandis, H. C. (1994). Culture and social behavior. New York: McGraw-Hill.

Valli, L. (1995). The dilemma of race: Learning to be color blind and color conscious. Journal of Teacher Education. 46(2), 120-129.

Vygotsky, L. S. (1962). Thought and language. Cambridge: MIT Press.

Woodson, C. (1933). The miseducation of the Negro. New York: Classic House Books.

DENISE ERKINE-MEUSA, EdD, is a recent graduate of Morgan State University. Her research interests include multicultural pedagogy, excellence in teaching, service and technology application in the classroom. 